\title{
Roman and Celtic Women in Roman Imperial time as shown in Latin epigraphic sources
}

\author{
Prof. (CN) Dr. phil. Gabriele Ziethen M.A.
}

AKSUM - Akademische Kurse,

Seminare und Mitarbeiterberatung

Ladies and gentlemen, dear colleagues,

I like to give my best thanks to our colleague Prof. Dr. Ophelia Fayez Riad and the Faculty of Arts of Cairo University for reading my paper in absentia of the author. For further discussion I propose to talk about questions via e-mail or during my stay at German Institute of Cairo University in April $06^{\text {th }}$ to April $15^{\text {th }}$ next month.

The question discussed in this paper with methods of language, history and archaeology seems to be simple: Can we find a special history of women?

The subject of this lecture is focused on the cultural intercourse between local Celtic culture in Middle Europe, esp. France and German River Rhine region, and the Roman culture in language, religion and social development. In this well researched field by ancient history, archaeology of the Roman provinces and studies in language and social subjects, mostly history of men's world is discussed to be an example for a phenomenon which is defined as "Interpretatio Romana", i.e. the structures between local traditional culture and the culture brought to West and Middle Europe after Roman occupation since the end of $1^{\text {st }}$ century BC and mostly during $1^{\text {st }}$ century AD. Looking through the rich field of epigraphic sources and also taking into consideration some small but very interesting literary sources, we find some interesting subjects belonging to the world of Celtic women, 
which were able to protect their cultural identity and deep roots of preRoman culture in a world of change and new definitions of lifestyle and personal identity.

After the Swiss lawyer Jakob Bachofen (1815-1887) has titled his main book "Das Mutterrecht. Eine Untersuchung der Gynaikokratie der alten Welt nach ihrer religiösen und rechtlichen Natur", European scholars started a long lasting academic discussion ${ }^{1}$ about the female contribution to "world-history". During the very conservative European $19^{\text {th }}$ century it was more common to reconstruct social life of ancient world and antique culture more by the specific understanding of the $19^{\text {th }}$ century authors instead by the facts of real ancient life. This meant: only a one-sided perspective to the definition of female life as marked by "marriage, children, home, kitchen and religion" instead of the manifold and truly existing of differences in belief, personal chance and living between traditional culture and managing their lives during an era of changing world. However, the small seed J. Bachofen has planted began to grow and after two World Wars in $20^{\text {th }}$ century the book by Simone de Beauvoir "Das andere Geschlecht. Sitte und Sexus der Frau (French: Paris 1949, German: Hamburg 2008, $4^{\text {th }}$ edition) became a shocking, irritating and well researched analysis unveiling a world of cultural suppression, non-rights, male-defined "gender and sexus" and controlled private and sexual life at all in past and present. Now the still suppressed subject was on the way to academic discussion. ${ }^{2}$ After social revolutions of 1968 finally sciences of history ${ }^{3}$ and archaeology learnt to use questions discussed from sociological perspective ${ }^{4}$ and after two additional decades later the small seed became a big tree of knowledge: another perspective to ancient world and the "forgotten" women of antique CeltoGraeco-Roman period began to "speak by their own voices". 5 So the female subjects in e.g. ancient Egyptian culture ${ }^{6}$, ancient Greek theater plays ${ }^{7}$, rhetoric sources ${ }^{8}$ or myths ${ }^{9}$ no longer were an exotic and far world to Middle European perspective, because for recent readers the world of 


\section{Gabriele Ziethen M.A}

women now became colored by their special traditions ${ }^{10}$ and poly-ethnic by their marriages ${ }^{11}$ and trans-cultural by their social and migrating movements ${ }^{12}$.

Comparing the objects in women's graves, results of modern archaeology have shown that Celtic women between $6^{\text {th }}$ century BC and $1^{\text {st }}$ century AD had the chance to keep their individual identity. They also were shown at Celtic coins (surely in their function as deitiy). ${ }^{13}$ Young girls wrote on their spinning utensils small inscriptions like "Geneta imi daga uimpi" I am a good and beautiful girl" or if their character was a little bit more brazen and saucy the short inscriptions were more erotic: "mattadagomota balineenata" - "well to screw" or "marcosior" - to be ridden". ${ }^{14}$

If they married far from their place of birth, they kept their special style of cloths and fashion at the place of their new home and new social environment as a special sign of personal identity, heritage and selfconsciousness. Together with their husband they managed the family's property by nearly equal rights. ${ }^{15}$

Women's names were preserved in later periods by Roman inscriptions, names of places and objects of daily life and especially by the names of Celtic goddesses ${ }^{16}$.

"Belisama" was the name of "the very mighty" and "Senobena" was "the old woman". The last mentioned name with the same root as Latin "senex" - the old (cf. Latin: senectus, senilis). We know e.g. the "duxtir" "daughter" (the same root in German: Tochter), "geneta" - girl (cf. "genos"tribe, family), "gnata"- daughter (cf. ancient Greek: génos and Latin [g]nasci), "rigana"- queen (Latin: regina), "uidla" - wise women/witch (vgl. Latin: videre and videri). ${ }^{17}$ In pre-Roman period the Celts used the Greek alphabet $^{18}$, later they changed for the Roman alphabet.

The first description of social status of Celtic and Germanic women of the north alpine pre-Roman culture were delivered by Roman and Greek 110 
authors (Caesar, Tacitus, Suetonius, Cassius Dio). It is interesting to notice that they mostly mentioned the social name or public "functional" name of the women instead of their true individual names. There surely was a special reason that the women secretly kept their individual name in order to be protected against any magic influence that could be caused by the "cultural" enemy. Interesting examples for such behavior also were the wise women Veleda and Albrinia, both were of Germanic ethnicity as Tacitus mentioned. ${ }^{19}$ These Germanic women received high reference and honours in the end of 1 st century $\mathrm{AD}$ by their own tribes and also by Romans. ${ }^{20}$ Veleda's name is shows $\sqrt{ } *$ uel - to see (cf. Latin: videre, videri) and Celtic root "veles", "veleta". Albrinia's name contains the word "runa" - written sign, oracle, secret, epic song. ${ }^{21}$ Both individuals were women of special knowledge and wisdom.

\section{Let us now have a look to daily life.}

It is interesting to see that after Romans had occupied the River Rhine region in the first half of the $1^{\text {st }}$ century $\mathrm{AD}$, we can find many women from Celtic descent, mostly from the Tribe of the Treveri, who lived between River Maas (Lat. Mosa), Mosel (Lat. Mosella) ${ }^{22}$ and Rhine (Rhenus).

Especially the "new media" of this time (e.g. inscriptions), which covered Celtic life when starting to write many subjects with Latin instead of the rare and only specially used Greek alphabet, have preserved precious epigraphic sources with biographic, social, economic, ethnic and religious data. We can find the Latinized versions of personal names in context of marriage, motherhood, widowhood ${ }^{23}$ which show the more conservative attempt of these Celtic women to preserve the former identity of their culture.

From the city of Bingen we know Lutoria Bodica who took care using her own property - for the burial of a daughter and the son-in-law. ${ }^{24}$ From Mainz we know a man named Bodico ${ }^{25}$, too. These names were 


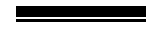

preserved until Late Antiquity and Medieval period being part of topographic names and other derivations. One of the most known bearers of this name was Britannic queen Boudicca who fought the battle against Romans in $43 \mathrm{AD}$. The root of the name is known from old Irish language (búaid) and means ,,victory, profit, excellence“ ${ }^{26}$

Another well known Celtic woman was Menimane, daughter of Brigo, and wife of Blussus, son of Atusirus; both of the couple that lived in Roman Mogonticum (Mainz) ${ }^{27}$ were from Celtic descent. ${ }^{28}$ Menimane took care for the burial of her husband, who as a "nauta" (owner of a ship, surely at River Rhine) died aged 75. ${ }^{29}$ The magnificent tombstone with two detailed Latin inscriptions and decorations on both sides shows that Menimane attached great importance to her individuality: even though her husband is portrayed with a semi-Roman style of cloth and the son (young generation!) with typical Roman style (tunica and Roman amulet), Menimane shows her traditional and precious Celtic costume (influenced by Greek peplos-style) $)^{30}$ and jewellery ${ }^{31}$ (Fig. 1). This attitude can be interpreted as a sign for only a slow and step-by-step approximation to the new Roman culture. The change from Celtic style of costume to typical Roman fashion took the time of three or four generations between the last decades of the $1^{\text {st }}$ century $\mathrm{AD}$ and the end of the $1^{\text {st }}$ century $\mathrm{AD}$ or very early beginning of the $2^{\text {nd }}$ century $\mathrm{AD}$ as we know from the objects in women's graves during this period. ${ }^{32}$

In the opposite men much easier tried to copy the Roman style mostly encouraged by the pressure to manage their life supply and career under Roman symbols and law. But for the women, there were existing very sensitive fields of their identity and cultural belief also described by ornamental decorations of their inscribed gravestones, which should be read together with the text to understand the sophisticated meaning of the whole composition and development. So finally after a long procedure of changing $11 \mathrm{~V}$ 
fashion, the iconographic code of women's tombstones in the provinces and also the iconography of their goddesses more and more was influenced by the official picture of the Roman empresses as they could be seen at Roman coins. ${ }^{33}$ However, these women did not change their names completely; they only Latinized their tribal names by using Latin endings.

\section{What had happened?}

After the Roman occupants recognized that for the Celtic as well as for the Germanic people female identity was connected with special religious factors, Roman government tried to control social and cultural life in a special way. Because of the fact that Italian-Roman deities were more single characters (no birth, no death, no special biography, no marriage excepting the relation of Jupiter and Juno, no monarchic structure of the celestial society) lacking a family or the special stories of celestial parents ${ }^{34}$, Romans met a strange other situation in Celtic culture: nearly every male god was connected with a female complement like in Greek culture. In addition the Germanic tribes along river Rhine worshipped not only male deities but also the triad ${ }^{35}$ of the mighty mothers (virgin-mother-old woman) and other goddesses. ${ }^{36}$ The roots of this belief can be found in the old prehistoric traditions of old Europe, as Marija Gimbutas ${ }^{37}$ has defined and Peter Herz ${ }^{38}$ has shown with the analysis of epigraphic sources of the Rhine region. Next to the Celtic druids - who for Roman government were enemy "number one" - the women as the more silent and persistent keeper of local culture came to the focus of politics in the new Roman provinces. ${ }^{39}$

\section{How was Roman action?}

Suetonius mentioned that Emperor Augustus made the experience that female hostages were more important than men. ${ }^{40}$ Finally either such precious female captives were "allowed" to return to their tribes if a ransom was paid (surely to make new contracts with the tribal leaders more safe) or 
such female hostages were sold by Romans and sent into regions far from the original homeland; and in addition these persons were forbidden to return to their tribal places for the time of thirty years (this is nearly the time of fertility of young women or one generation or the best time for social education by the winners definition).

Such kind of strong politics set hostile tribes under pressure, strengthened those of tribal leaders which declined for the Roman side and finally the wise women were separated from their traditional places. So at the end, both the Celtic druids and the Celtic and Germanic wise women lost their political influence.

The result was that in the end of $1^{\text {st }}$ century Roman commissions and high ranking members of Roman religious societies travelled to local provincial sanctuaries ${ }^{41}$ to be informed about the local cult places. Many Celtic and Germanic gods and religious elements became an integrated part of Roman provincial religions and many individual cults of worshipping were allowed. ${ }^{42}$ However, the important cult of the local mothers (matronae) never became an integrated or adopted part of official Roman religion!

\section{How was female re-action?}

Many of Provincial women started to live together with Italian soldiers or auxiliary soldiers from other provinces after all local tribes (in conclusion: the men and ethnic chiefs) more and more lost their property of land to the Romans by new Roman law's definition (the former owners by juridical way became strangers/peregrini at their former territory). However, for children of the aforementioned Provincial-Roman families there was a good chance to receive complete Roman citizenship after the Roman father or soldier from the auxiliary finished his military service by honourable discharge (honesta missio) after 20-25 years of military 
service $^{43}$. Indeed, the highest risk for these Provincial women was that her partner died before his discharge. ${ }^{44}$ Surely such new situation of living-style was orientated to the future of the children (which became Latin speaking young Romans) and therefore the women kept their personal ethnic and cultural identity a longer time than men have done. And in the opposite the cult of the former local deities was preserved because of the Roman tolerance towards the social status of motherhood. So by risky but clever marriage (and the hope of a good fate) these women brought back the "lost" land of their ancestors by the inheritance of the children's Roman fathers. ${ }^{45}$

\section{Now the final question:}

Did the old female symbols secretly survive after Roman occupation?

Very rare sources of old European cultural structures show nearly forgotten signs, which lead us back to the deep and far origins of communication in ancient, pre-Roman and early Roman cultures of Middle Europe. At the territory of a Roman villa rustica near NeidensteinWaibstadt (close to Heidelberg, Germany) there was an altar dedicated to the Matrones Alhiahenes (matronis Alhiahenabus) by a certain Iulius Veranius Super in his own name and for his family (pro se et suis) (Fig. 2). Upon the typical Latin inscription there is a first line with additional symbols (Fig. 3) which to my mind are not a simple graphic decoration but more a system of special communication. Surely these symbols (and not the altar itself which is very common for the Roman period at all) were one of the reasons that the antique altar was "Christianized" for rites of baptism after excavation in $19^{\text {th }}$ century. And finally in $19^{\text {th }}$ century the altar was taken away from liturgical use by Christian-catholic church. ${ }^{46}$

It is interesting to compare the mentioned line with a couple of symbols which is in use since Antiquity and Middle Ages until nowadays: woven goods (esp. belts) ${ }^{47}$ in the Baltic States show until today such 
symbols. Compared with very old systems from Latvian weaving we possibly can read the basic signs as cosmic symbols with sun and stars, tree of the world, symbols of protection, luck and energy ${ }^{48}$ : the non-Latin inscription possibly cleverly veiled the secret meaning of the very old and mighty triad of the mothers/matrones worshiped by Iulius Veranius Super and his family.

The selected examples show how a reconstruction of female life, belief and individual energy can be proposed, if the scholarly perspective truly likes to ask new questions in order to discover the nearly lost paths of antique women's life, love and language.

In conclusion to the introducing question: Can we find a special history of women? - "Yes, we can".

Figures:

$|r|$ 


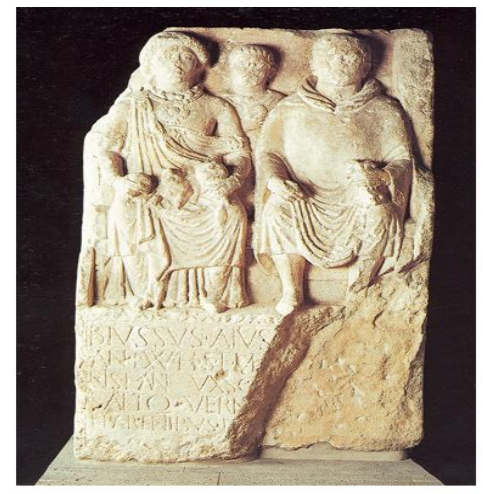

Fig. 1: Menimane and Blussus (Mainz-Weisenau, Germany). - W. Selzer/K. V. Decker/A. DoPaço, A., Römische Steindenkmäler. Mainz in Römischer Zeit. Katalog zur Sammlung in der Steinhalle (Mainz 1988) 96 fig. 60.

Neidenstein (near Heidelberg. Germany)

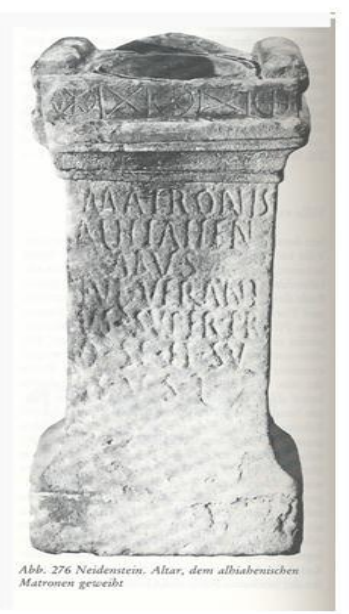

Fig. 2: Neidenstein (close to Heidelberg), Roman altar dedicated to the Matrones Alhiahenes. - Ph. Filtzinger/D. Planck/B. Cämmerer (eds.), Die Römer in Baden Württemberg (Stuttgart/Aalen 1986, 3rd.ed.) 456 fig. 276. 


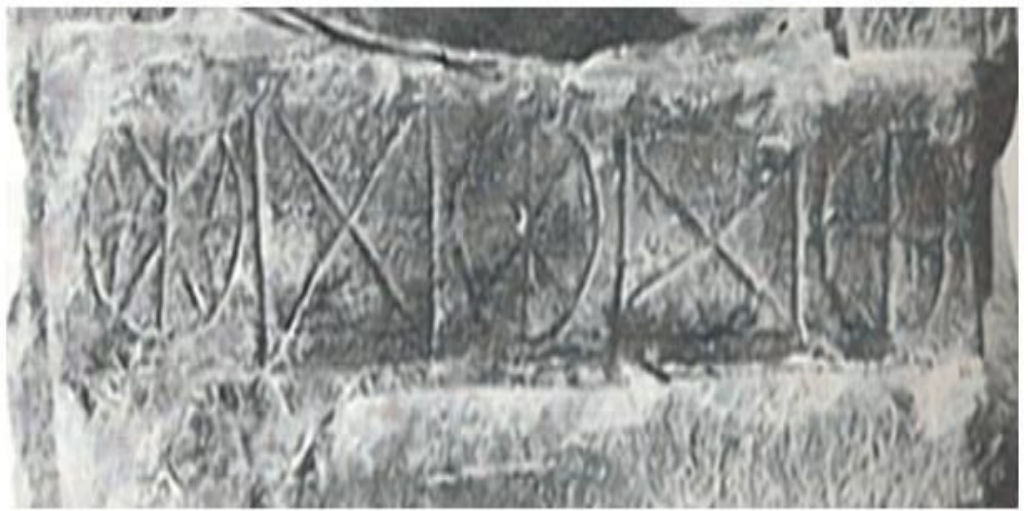

- 1. two horizontal lines, symbols between, vertical lines: symbols of earth and heaven, femine and male world.

- 2.circle: kosmos, energy, sun, return of the agricutural year.

- 3. star +cross or small tree cosmic energy or tree of the world

- 4. X-cross. symbol of protection, worshipping of the sun

- 5. circle with symbol of star (three crossing lines). special star (morning stariNenus?)

- 6. like 4

- 7. cross with + firecross/swastika symbol of luck and protection, energy

Fig. 3: Detail from Fig. 2 with proposal of interpretation and reading. 


\begin{abstract}
Notas
* I like to give my best thanks to our colleague Prof. Dr. Ophalia Fayez Riad and the Faculty of Arts of Cairo University for reading my paper in absentia of the author. The subject discussed with this paper is the brief summary of two seminars (held at Johannes Gutenberg-University, Mainz, Germany, 20072008) about the meaning of female deities in ancient European culture and the history of women and female lifestyle in the Roman Provinces in Gaul and the regions of River Rhine and Danube.

1 B. Wagner-Hasel, B. (ed.), Matriarchatstheorien der Altertumswissenschaft (Darmstadt 1992).

2 G. Duby/M. Perrot, M. (ed.), Geschichte der Frauen Bd. 1. Antike (Frankfurt/M., New York 1993). - W. Schuller, Frauen in der griechischen und römischen Geschichte (Konstanz 1995). - Th. Späth/B. Wagner-Hasel (ed.), Frauenwelten in der Antike. Geschlechterordnung und weibliche Lebenspraxis (Darmstadt 2000).

3 Cf. V. Zinserling, Die Frau in Hellas und Rom (Stuttgart 1972). - B. Kreck, Untersuchungen zur politischen und sozialen Rolle der Frau in der späten römischen Republik (Diss. Marburg 1975).

4 With discussion of English and French publications (cf. ann. 2): Chr. v. Braun, Chr./Stephan, I. (ed.), Gender Studien. Eine Einführung (Stuttgart/Weimar 2000). - H. Bußmann/R. Hof, (ed.), Genus. Geschlechterforschung/Gender Studies in den Kultur- und Sozialwissenschaften (Stuttgart 2005). - S. Heine, Wiederbelebung der Göttinnen. Zur systematischen Kritik einer feministischen Theologie (Göttingen 1987).

5 B. Kytzler, Frauen in der Antike. Von Aspasia bis Zenobia (DüsseldorfZürich 1995)

6 J. A. Tyldesley, J. A., Die Töchter der Isis: die Frau im alten Ägypten (München 1996).

7 M. R. Lefkowitz, Die Töchter des Zeus. Frauen im alten Griechenland (München 1992).

8 K. Brodersen, (ed.), Frauen vor Gericht - Antiphon, Gegen die Stiefmutter (Apollodoros, Gegen Neaira (Demosthenes 59) (Darmstadt 2004).

9 P. J. Geary, Am Anfang waren die Frauen. Ursprungsmythen von den Amazonen bis zur Jungfrau Maria (München 2006).

10 W. Spickermann, W., Mulieres ex voto. Untersuchungen zur Götterverehrung von Frauen im römischen Gallien, Germanien und Rätien (1.-3. Jahrhundert n. Chr.). Bochumer historische Studien/Alte Geschichte 12 (Bochum 1994).

11 For example: Celtic women who married Roman/Italian soldiers who were garrisoned at River Rhine and Danube.
\end{abstract}


12 G. Ziethen, Ex Oriente ad Rhenum - Orientalen im römischen Mainz. Mainzer Archäologische Zeitschrift 4, 1997, 111-186 (with detailed bibliography).

$13 \mathrm{Cf}$. golden coins (stateres) minted in Western France by the Celtic tribe of the Redones (3rd/2nd century BC). See: Alltag und Pracht. Die Entdeckung der keltischen Frauen. Mit Texten von R. Cordie u.a. Sonderausstellung Archäologiepark Belginum, 25.2.-1.7.2007. Schriften des Archäologieparks Belginum 6 (2007)18 fig. 44.

14 Alltag und Pracht (ann. 13) 5 fig. 5 (all examples from Musée Rodin, Autun, France; 1st/2nd century AD). - Analysis of special terms in Celtic languages: X. Delamarre, Dictionnaire de la langue gauloise (Paris 2003, 2nd ed.).

15 Alltag und Pracht (ann. 13) 12sq.

$16 \mathrm{G}$. Behrens, Germanische und keltische Götter in römischem Gewand. Zentralmuseum für Deutsche vor- und Frühgeschichte in Mainz, Wegweiser 18 (Mainz 1944). - K. Derungs, (ed.), Keltische Frauen und Göttinnen. Matriarchale Spuren bei Kelten, Pikten und Schotten (Bern 1995).

17 Alltag und Pracht (ann. 14) 5.

18 From the oppidum of Bribracte we know a certain women named "Materias" (cf. Greek mêtêr; lat. mater, celt. *matir), whose name was written in Greek letters; Alltag und Pracht (ann. 14) 5 fig. 3.

19 Tacitus, hist, 4,65.4; 5,22.3; 5,24.1; 5,25.1; 5,25.3. - Tacitus, Germania 9,2. For the names see X. Delamarre (ann. 14). - Cf. Sueton, v.Claud. 1,2 (Drusus Maior)

$20 \mathrm{Cf}$. Ganna, a wise woman from the tribe of the Semnones, who lived at the court of Emperor Domitian (Cass. Dio 67,5.3). From the same tribe a certain Walburg (B $\alpha \lambda \beta$ ov $\rho \gamma)$ is known from Egyptian Ostrakon, 2nd century AD (E. Schröder, in: Arch. Rel.wiss. 19, 1919, 196sq.).

21 On the traditions of „auspicia“ - omens and „sortes“ - holy lots: Tacitus, Germania, 9,1-2; 10,1-3. - Suet. Vit. 14,5.

22 Latin „Mosella“ - German „Mosel“ means the „small River Maas“.

23 A. Dierichs, Von der Götter Geburt und der Frauen Niederkunft (Mainz 2002). - M. Eichenauer, Untersuchungen zur Arbeitswelt der Frau in der römischen Antike (Frankfurt a. M. 1988). - B. E. Stumpp, Prostitution in der römischen Antike (Berlin 1998). - E. Herrmann-Otto, Unfreie Arbeits- und Lebensverhältnisse von der Antike bis in die Gegenwart : eine Einführung (Hildesheim 2005). - G. Heyse, Mulier non debet abire nuda : das Erbrecht und die Versorgung der Witwe in Rom. Europ. Hochschulschr. Rh. 2 Bd. 1541 (Frankfurt a.M. 1994). - J. U. Krause, Witwen und Waisen im Römischen Reich. Heidelberger althistorische Beiträge und epigraphische Studien, 4 vls. (Stuttgart 1994-1995). 
- Roman and Celtic Women in Roman Imperial time as shown in Latin

24 Corpus Inscriptionum Latinarum XIII 7591 (Bingen): D(is) M(anibus) / Focuronie / Pat/te filie et Firmi / nio [.]esinto ge / nero s[uo] Lutoria / Bodic[a] mater / de suo [vi]va pos[u]it.

25 Corpus Inscriptionum Latinarum CIL XIII 6740a.

26 D. Ellis Evans, Gaulish Personal Names. A Study of some Continental Celtic Formations (Oxford 1967)156sqq. - G. Ziethen, Römisches Bingen - Vom Beginn der römischen Herrschaft bis zum 3. Jahrhundert n. Chr. In: Vom Faustkeil zum Frankenschwert. Bingen, Geschichte einer Stadt am Mittelrhein, hrsg. von A. Heising/G. Rupprecht (Mainz 2003) 23-107, esp. 83sq.

27 For the roots of the city's name cf. ann. 36.

28 A. Böhme-Schönberger, Das Mainzer Grabmal von Menimane und Blussus als Zeugnis des Romanisierungsprozesses. In: Provinzialrömische Forschungen (1995) 1-11. - W. Boppert, Der Blussusstein. - Das Grabmal eines einheimischen Aufsteigers. Mainzer Zeitschr. 87/88, 1992/93 [1995], 345-378. - G. Ziethen, Vom Legionslager zur Provinzhauptstadt. In: Mainz. Die Geschichte der Stadt, hrsg. von F. Dumont. F. Scherf u. F. Schütz (Mainz 1998 = Mainz 21999) 39-67, esp. 62sq.; M. Witteyer, Mogontiacum - Militätbasis und Verwaltungszentrum. In: loc. cit. 1021-1058, esp. 1025.

29 W. Selzer/K. V. Decker/A. DoPaço, A., Römische Steindenkmäler. Mainz in Römischer Zeit. Katalog zur Sammlung in der Steinhalle (Mainz 1988) 95-98, 168sq. no. 110.

$30 \mathrm{Cf}$. ann. 47.

31 Cf. ann. 28. - A. Böhme-Schönberger, hautnah. Römische Stoffe aus Mainz (Mainz 2009) 41-45.

32 Many examples in: Gräber - Spiegel des Lebens. Zum Totenbrauchtum der Kelten und Römer am Beispiel des Treverer-Gräberfeldes Wederath-Belginum, hrsg. von G. Haffner u.a. ( Mainz 1989). R. Cordie, (ed.), Archäologiepark Belginum (Mainz 2005). - M. Witteyer/P. Fasold et al., Des Lichtes beraubt. Totenehrung in der römischen - Gräberstraße von Mainz-Weisenau (Wiesbaden 1995); M. Witteyer, Mogontiacum (ann. 28).

33 A. Dierichs, Das Idealbild der römischen Kaiserin: Livia Augusta. In: Th. Späth/B. Wagner-Hasel (ed.), Frauenwelten (ann. 2) 241-262, esp. 258-261.

34 This is one of the main differences between the Italic-Roman deities and Greek Olympic deities.

35 Cf. G. Dumézil, Les dieux des Indo-Européens (Paris 1952)., id., Rituels indoeuropéens à Rome (Paris 1954). - In 2005 the National Museum of Archaeology, Lissabon, Portugal, has shown the subject by a special exhibition on the culture of Western Celts. - H. G. Kippenberg, Magie. In: H. Cancik/B. Gladigow/K.-H. Kohl (eds.), Handbuch religionsgeschichtlicher Grundbegriffe 4 (1998) 85-98. 
36 Cf. some selected examples from the middle Rhine region (G. Behrens loc.cit. ann. 16 and X. Delamarre pass. loc. cit. ann. 14): Aveta: vgl. Celt. aui-, auitianos-desire, goddess of desire?; Epona: goddess of horses Göttin der Pferde (Celt. epos/Greek: híppos); Meduna: goddess of Met-drink/of drunkenness?; Mogontia: the mighty/big goddess (goddess of the plain?, the male complementary was Mogon; these deities' names are also known in Gaul and in Great Britain), vgl. * magos, gr. makros, lat. magnus; Maia (*magia zu skr. mahī); Ritona: goddess of crossing (a river); Sirona: goddess of a star (cf.. $\mathrm{S}(\mathrm{t})$ irona - young cow), goddess of a star and of fertility; Virodactis: cf. Uiriodacus; goddes of men (?) or goddess of truth (?); cf. *uīro-truth or. *uiro-man, human, Latin: vir; Sunuxsal: cf. sounos/dream, Latin: somnus; goddess of dream (?); tribal deity of the Sunuci; Icovellauna: cf. pic-top of a mountain (Raetoromanic in Switzerland: piz), ico-uellaunos-chief, commander; possible also name of an animal, cf. Latin. picus-green woodpecker; Visuna: cf. the Germanic Uesuniahenae Matronae: the kind/benevolent goddess; Nantosuelta: *nantu, nanto - valley, brook; -suelta from *sonnocingus and similar terms; meaning: goddess from the the sunny (brook?) valley (?).

37 M. Gimbutas, Die Balten. Geschichte eines Volkes im Ostseeraum (München/Berlin 1983). - id., The Goddesses and Gods of Old Europe (London 1982). - id., The Language of the Goddess (New York 1989). - Cf. R. Katicić, Auf den Spuren sakraler Dichtung des slawischen und des baltischen Heidentums. Vorträge Nordrhein-Westfl. Akad. Wiss., Geisteswiss. 377 (Wiesbaden 2001).

38 P. Herz, Einheimische Kulte und ethnische Strukturen. Methodische Überlegungen am Beispiel der Provinzen Germania Inferior, Germania Superior und Belgica. In: H. E. Herzig/R. Frei-Stolba (eds.), Labor omnius unus. Festschr. G. Walser (Stuttgart 1989) 206-218, esp. 217sq.

39 J. de Vries, Keltische Religion (Stuttgart 1961). - T. Derks, Gods, temples and ritual practices: the transformation of religious ideas and values in Roman Gaul (Amsterdam 1998).

40 Suetonius, v.Aug. 21,2.

41 Corpus Inscriptionum Romanum XIII 7253 (Dessau, Inscriptiones Latinae Selectae 1010).

42 W. Spickermann, W., Mulieres ex voto. Untersuchungen zur Götterverehrung von Frauen im römischen Gallien, Germanien und Rätien (1.-3. Jahrhundert n. Chr.). Bochumer historische Studien/Alte Geschichte 12 (Bochum 1994).

43 H. Cüppers (ed.), Die Römer in Rheinland-Pfalz (Stuttgart 1990) 76sqq.

44 In such case there was not granted the ius connubii (Roman marriage) with the husband's pension or property; cf. ann. 23. 
- Roman and Celtic Women in Roman Imperial time as shown in Latin

45 There are also records that the proud Roman fathers after their pension served in Roman army a second or third time (with double or triple sold) together with their young sons; such decision brought much more money to the whole families including the Provincial granfathers.

$46 \mathrm{Ph}$. Filtzinger/D. Planck/B. Cämmerer (eds.), Die Römer in Baden Württemberg (Stuttgart/Aalen 1986, 3rd ed.) 456sq. fig. 276.

$47 \mathrm{Cf}$. the still vivid discussion about the connection between the lands of amber and the Graeco-Roman world. I give my thanks to the friendly ladies of staff at National History Museum of Latvia, Rịga, who explained me in 2006 the long tradition of the сарафан (saraphan)-like female costume which possibly during Iron age could be influenced by the Greek peplos. I. Stašulāne (red.), Sēli un Sēlija - Selonians and Selonia, ed. by Latvijas Nacionālais Vēstures muzejs (Rìga 2005) 11 sqq. - Geschichte Lettlands "Der Weg von den Wikingern zu den Griechen", ed by Latvijas Institūts (Rīga 2000).

48 D. Kraukle, Latvian Design (Riga 2006) 16sq., 21, 27, 45, 57. 